\title{
Pandemija COVID-19 i novo razumijevanje sigurnosti
}

\author{
SINIŠA TATALOVIĆ \\ Fakultet političkih znanosti, Sveučilište u Zagrebu \\ DARIO MALNAR \\ Hrvatsko vojno učilište "Dr. Franjo Tuđman”, Zagreb
}

\begin{abstract}
Sažetak
Izbijanje pandemije COVID-19 početkom 2020. dovelo je do nezabilježene krize globalnih razmjera koja je dovela do blokade vitalnih sastavnica društvenog djelovanja u razmjerima koji su ugrozili međunarodnu i nacionalnu sigurnost. Pandemija je iskazala potencijal za evoluciju i generiranje šireg spektra prijetnji i otvorila suštinska pitanja razumijevanja sigurnosti i sigurnosnog organiziranja država. Radi se o prijetnji na koju, iako je prepoznata u većini strateških dokumenata sigurnosti, nije uspješno definiran odgovor nacionalnih i međunarodnih sigurnosnih sustava u okviru još uvijek dominantnog razumijevanja sigurnosti utemeljenog na tradicionalnim sigurnosnim studijama. Pokazalo se da su sigurnosni sustavi još uvijek determinirani tradicionalnim konceptom koji ne omogućava u potpunosti prepoznavanje uzroka prijetnji i kriza te njihove korelacije, što jača neizvjesnost i negativno utječe na normativni i institucionalni kapacitet potreban za učinkovit odgovor na krize. Rad polazi od hipoteze kako je pandemija COVID-19 potaknula promjene sigurnosne paradigme, što znanstvenu zajednicu i donositelje političkih odluka stavlja pred izazov definiranja novih pristupa i novih metoda istraživanja sigurnosnih fenomena te strateškog modeliranja sigurnosnih sustava i upravljanja krizama na nacionalnoj i na globalnoj razini. U radu će se stoga analizirati utjecaj krize potaknute pandemijom COVID-19 na razumijevanje sigurnosti kroz raščlambu prijetnji koje je generirala te definiranje korelacije teorijskih znanja i praktičnih iskustava upravljanja krizom.
\end{abstract}

Ključne riječi: pandemija COVID-19, sigurnost, sigurnosne politike, sigurnosne studije, upravljanje krizama 


\section{Uvod}

Sigurnost promatrana kao poželjno stanje i kao društveni sustav oduvijek je privlačila pozornost znanstvenika iz različitih znanstvenih disciplina. Kako su se razvijala društva, tako su evoluirali i pristupi izučavanja sigurnosti, posebno nakon završetka Hladnog rata i afirmacije sigurnosnih studija kao znanstvene discipline. Sigurnost kao stanje, prema Arnoldu Wolfersu, ima dvije dimenzije, objektivnu i subjektivnu, koje se definiraju, kako s razine pojedinca tako i s razine društva, kao kolektivna percepcija. Sigurnost se ne odnosi samo na "odsustvo prijetnji stečenim vrijednostima", već i na "odsutnost straha da će te vrijednosti biti ugrožene" (Wolfers, 1962, str. 150151). To su dvije temeljne varijable koje sigurnost čine promjenjivom kategorijom. Kada se radi o ugrozama kao što su zdravstvene, za ponašanje različitih subjekata, od pojedinaca do država, važniji je njihov subjektivni osjećaj sigurnosti od objektivnog stanja, čak i kada bi ga bilo moguće znanstveno izmjeriti. Pored toga, intenzitet straha u odnosu na neku opasnost rijetko se u potpunosti poklapa s objektivnim, odnosno stvarnim potencijalom opasnosti da se nekoga ili nešto ugrozi ili mu se nanese šteta. Takvo razumijevanje sigurnosti iz perspektive jednog od najvažnijih predstavnika političkog realizma dobro je teorijsko polazište za izučavanje različitih aspekata suvremene sigurnosti. Međutim za istraživanje suvremenih sigurnosnih izazova to nije dovoljno. Zbog globaliziranog svijeta koji podrazumijeva slobodno kretanje ljudi, roba i kapitala važno je koristiti i liberalnu teoriju, posebno kada se razmatra suodnos države i privatnog sektora. To je posebno važno u pojedinim sektorima, kao što je zdravstveni sustav, gdje se snažno isprepleću javni i privatni interesi. Ipak, sigurnosne teme i njihovo istraživanje danas su toliko raznorodni i složeni da pojedina pitanja nije dovoljno analizirati samo iz jedne teorijske perspektive, nego u njihovoj kombinaciji. Polazeći od spoznaje da se realistički i liberalni pristupi relativno sporo mijenjaju, a da su društvene promjene, posebno u području sigurnosti, vrlo česte i brze, u sigurnosnim studijama sve je zastupljeniji konstruktivistički pristup:

Uvelike nadilazeći obuhvat suvremenih vladajućih teorija sigurnosti, konstruktivizam je osobito važan zato što sigurnost pojedinaca i država prikazuje kao društvene konstrukte koji s vremenom podliježu bezgraničnim preformulacijama aktera, a ne kao statičan koncept vezan uz odredive i nepromjenjive uvjete, kako običavaju pretpostavljati realisti i neorealisti. Sve se više teoretičara i praktičara međunarodnih odnosa oslanja na konceptualne alate konstruktivizma, osobito na napuštanje uobičajenih shvaćanja uzročnosti i empirijske teorije pri promišljanju međunarodne politike i sigurnosti (Kolodziej, 2011, str. 206).

Tradicionalno je dominirala percepcija sigurnosti koja se definirala kroz sigurnost jedne političko-sigurnosne zajednice, države, u odnosu na drugu političko-sigurnosnu zajednicu. Takav pristup uzrokovao je dominaciju vojnog aspekta sigurnosti, što je dovodilo do pojave sigurnosne i obrambene dileme. Završetkom Hladnog 
rata i liberalizacijom međunarodnih odnosa došlo je do proliferacije aktera sigurnosti i njihovih međusobnih odnosa. Procesi proteklih tridesetak godina ukazuju da se sigurnost, odnosno nesigurnost sve više pomiče iz vojne prema nevojnoj sferi, a uz države na te procese snažno djeluju novopozicionirani nedržavni akteri, međunarodne terorističke skupine i organizirane kriminalne skupine te prirodni procesi vezani uz klimatske, demografske i zdravstvene procese i uvjete. Istovremeno dolazi do generiranja novih opasnosti za čovjeka, društvo i okoliš, ${ }^{1}$ a rezultanta njihovih ukupnih djelovanja kreće se između sigurnosti i nesigurnosti. Danas gotovo da nema aspekta društvenog, državnog ili međunarodnog konteksta koji ne poprima sigurnosna obilježja, odnosno mogućnost sekuritizacije. Zbog toga se danas svako pitanje može nametnuti i kao sigurnosno pitanje (Tatalović i Malnar, 2015, str. 24).

Ovisno o kretanju percepcije sigurnosti, odnosno nesigurnosti, pomicali su se i prioriteti država i drugih aktera u njihovom organiziranju i pristupanju funkciji vlastite sigurnosti. I u tom razdoblju proširenog koncepta sigurnosti prioriteti su bili usmjerenost na opasnosti koje dolaze od drugih država te sada i nedržavnih aktera, a manje na prijetnje koje dolaze iz prirodnog okoliša. Na to je utjecala percepcija država da s postojećim kapacitetima kao što su civilna zaštita te zdravstvene i socijalne službe mogu učinkovito odgovoriti na prijetnje kao što su elementarne nepogode, tehnološke katastrofe te prijetnje zdravlju, epidemije i pandemije. Stoga te prijetnje, iako uočavane i definirane u kontekstu prijetnji sigurnosti, nisu bile sekuritizirane na način da se sigurnosne politike i sigurnosni aparati u odnosu na njih koherentno modeliraju. Rizici od tih prijetnji nisu se sagledavali u interakciji s drugim prijetnjama. To su pretpostavke na kojima se modelirala prevencija i izgradnja nužnih kapaciteta za krizno upravljanje i djelovanje. Izvanredni događaji povezani s tim prijetnjama u pravilu su imali lokalni ili regionalni karakter (čak i na nacionalnoj razini), a u njihovom zaustavljanju i saniranju posljedica uglavnom je bilo dovoljno djelovanje lokalnih snaga. U iznimnim slučajevima iskazivana je međunarodna solidarnost i pomoć globalne zajednice.

Pandemija COVID-19 to je razumijevanje prijetnji u potpunosti promijenila i pokazala se kao prijetnja koja je najjače ugrozila sigurnost država i pojedinaca još od 2. svjetskog rata. Visoki predstavnik EU-a za vanjsku i sigurnosnu politiku i potpredsjednik Europske komisije Josep Borrell Fontelles (2021, str. 44) ocjenjuje kako je "od početka pandemije bilo jasno da će COVID-19 preoblikovati svijet"

1 To uočavaju i predstavnici Kopenhaške škole koji su definirali proširen i produbljen koncept sigurnosti kojim se sigurnost promatra kroz više sektora - politički, ekonomski, vojni, socijetalni i okolišni - te na više razina, od međunarodne do razine pojedinca. Vidi šire u: Buzan, B., People, States and Fear. The National Security Problem in International Relations, Wheatsheaf Books, Brighton, 1983; Buzan, B., People, states and fear: An agenda for international security studies in the post-Cold War era, Hemel Hempstead, Harvester, 2. izd., 1991; Buzan, B., Wæver, O., Wilde de, J., Security: A New Framework for Analysis, Lynne Rienner, London, 1998. 
te da možemo biti sigurni kako će po okončanju krize "naš svijet izgledati bitno drugačije". Time se potvrđuje kako globalizacijskim procesima omogućeno, ranije nezabilježeno, neograničeno komuniciranje i kretanje ljudi dovodi, uz određene negativne okolnosti, ${ }^{2}$ do opasnosti prerastanja lokalnih izvora ugrožavanja, kao što je slučaj s COVID-19, u globalne pandemije i prijetnje. Nešto što bi u prošlosti bila epidemija ograničenih razmjera danas neočekivano i vrlo brzo može postati opasna pandemija koja ima globalni doseg, koja uz zdravlje ljudi ugrožava i razne druge aspekte društvenog života te koja postaje sveobuhvatna prijetnja osobnoj, nacionalnoj i međunarodnoj sigurnosti.

Zbog nedovoljne svijesti o toj mogućnosti i u slučaju pandemije COVID-19 mnoge zemlje zakasnile su s aktiviranjem mehanizama kriznog upravljanja i posljedično s poduzimanjem potrebnih mjera. Tome je pridonosilo i nesnalaženje Svjetske zdravstvene organizacije (WHO), kao globalnog koordinatora zdravstvene sigurnosti. Mora se napomenuti i još uvijek prevelika zatvorenost zdravstvenih sustava $i$ nespremnost dijeljenja svih relevantnih informacija o ovoj vrsti prijetnje, ${ }^{3}$ što je posebno bilo izraženo kod autoritarnih političkih sustava. U tom kontekstu, bez namjere bavljenja svim aspektima pandemije COVID-19, u radu će se obrađivati samo njen utjecaj na promjene u sigurnosnoj paradigmi kao načinu promišljanja sigurnosti na nacionalnoj i globalnoj razini. Već sada se može uočiti da će se promijeniti percepcija građana u odnosu na potencijalne opasnosti te da će biti spremni podržati politike koje će se fokusirati na njihovu zaštitu. Iskustva mnogih država, pa i onih najmoćnijih kao što su SAD, Kina i Rusija, pokazalo je njihovu nemoć u odgovoru na ovu opasnost klasičnim instrumentima nacionalne moći (vojska, sigurnosni sustav). Pokazala se potreba sinergije djelovanja klasičnih sastavnica sustava nacionalne sigurnosti (vojska, policija, sigurnosno-obavještajne službe, civilna zaštita) sa zdravstvenim i obrazovnim sustavom. Začeci takvog razvoja već se mogu uočiti kroz odgovor na izazov pandemije COVID-19 i djelovanje kriznih sustava.

Analiza polazi od hipoteze kako je pandemija COVID-19 potaknula promjene sigurnosne paradigme na način da će uz klasične aspekte generirane geopolitičkim sučeljavanjima sila jačati meki instrumenti nacionalne moći i osviještenost građana o važnosti njihove, nacionalne i globalne sigurnosti, što će utjecati na transformaciju sigurnosnih politika i sustava. Takvo stanje znanstvenu zajednicu i donositelje političkih odluka stavlja pred izazov definiranja novih pristupa i novih metoda istraživanja sigurnosnih fenomena te strateškog modeliranja sigurnosnih sustava $i$ upravljanja krizama na nacionalnoj i na globalnoj razini. Valja imati na umu, kao što to navodi Gardini, da je upravo sada dok još traje epidemija i dok su svi dioni-

2 Zakašnjelo obavještavanje globalne zajednice, prikrivanje podataka, nesnalažljivost nadležnih međunarodnih organizacija i nespremnost nacionalnih sustava sigurnosti.

3 Kina, Rusija, Iran. 
ci senzibilizirani pravi trenutak za analizu i planiranje boljeg i otpornijeg sustava. Kada kriza prođe, javljaju se novi prioriteti, a senzibilitet i spremnost za potrebne promjene slabi (Gardini, 2020, str. 2).

Ova analiza, uz ograničenje da proces suzbijanja pandemije još ni približno nije završen, bavit će se komparativnom analizom djelovanja globalnih aktera kao što su SAD, Kina, Rusija te Republike Hrvatske i lokalnih aktera u njenom susjedstvu, Mađarske, Slovenije, Italije, BiH i Srbije, u razdoblju prvog vala pandemije u prvih šest mjeseci 2020. Usporedit će se odnos prema pandemiji/epidemiji kao prijetnji sigurnosti, koji je sadržan u strateškim dokumentima analiziranih država, te razina, posljedice i odgovori na tu prijetnju.

\section{Pandemija COVID-19 - strateško iznenađenje i globalna kriza}

Prvi slučajevi zaraze SARS-CoV-2 virusom, poznatijim kao COVID-19 zabilježeni su tijekom prosinca 2019. Već u samim tim počecima u svijetu se proširila zabrinutost zbog visoke virulentnosti virusa i brojnih nepoznanica o strukturi, nastanku i ishodištu širenja virusa. Te su se zabrinutosti vrlo brzo potvrdile snažnim širenjem virusa na globalnoj razini. ${ }^{4}$ Pandemija COVID-19 s ishodištem u kineskom gradu Wuhanu od izbijanja do sredine svibnja 2021. zahvatila je 220 država i teritorija, zabilježeno je 158.561 .398 slučajeva zaraze koje je pratilo 3.300 .335 smrtnih ishoda (Worldometer, 2021). Usporedbe radi, prema podacima Global Terrorism Indexa, tijekom 2018. godine terorizam je prouzročio 15.952 smrti, a zahvatio 71 državu (Institute for Economics \& Peace, 2019). Pandemija COVID-19 i mjere koje su se poduzimale za sprječavanje njenog širenja doveli su do značajnih negativnih gospodarskih posljedica. Pad BDP-a na globalnoj razini u lipnju 2020. MMF je procjenjivao na 4,9\% (PewResearch Center, 2020), a Svjetska banka na čak 5,2\% (World Bank, 2020). Radi se o padu većem od onog tijekom velike recesije izazvane financijskom krizom 2007./2009. kada je globalni BDP pao za 4,3\% (Federal Reserve History, 2013). Do tako snažnog pada i krize došlo je unatoč ranije nezabilježenim potporama gospodarstvu u mnogim državama, a Svjetska banka procjenjuje kako će se recesija dodatno produbljivati s produžavanjem pandemije (World Bank, 2020).

Podaci pokazuju kako se radilo o strateškom iznenađenju kako ga definira Kam. ${ }^{5}$ Radilo se o neočekivanom i iznenađujućem izbijanju krize, sustav ranog

${ }^{4}$ Svjetska zdravstvena organizacija (WHO) 4. siječnja 2020. je na društvenim mrežama izvijestila o klasteru plućnih oboljenja u kineskom gradu Wuhanu - bez smrtnih slučajeva. Već 14. siječnja 2020. predstavnici WHO-a su na brifingu za novinare izvijestili kako je zabilježen prijenos koronavirusa s čovjeka na čovjeka te da postoji rizik šire epidemije (World Health Organization, 2020a).

${ }^{5}$ Kam navodi da koncept iznenadnog napada sadrži tri glavna elementa. Prvo, iznenadni napad je vojni čin koji nije u skladu s žrtvinim očekivanjima i pretpostavkama. Drugo, napad iznena- 
upozoravanja zakazao je u njenoj detekciji i iskazala se nepripremljenost kako u organizacijskom i logističkom tako i, što je posebno zabrinjavajuće, u konceptualnom smislu na nacionalnoj i globalnoj razini. Međutim iako se u slučaju pandemije COVID-19 radilo o iznenađenju koje je pokazalo nespremnost gotovo svih aktera za takve situacije, "virus nije bio 'crni labud', dakle nije se radilo o rijetkom događaju koji je teško predvidjeti. Specijalisti za infektivne bolesti godinama su upozoravali na rastući rizik izbijanja pandemije"; uz to je "u proteklih dvadeset godina COVID-19 treći koronavirus koji se pokazao sposobnim za prijelaz s jedne na drugu vrstu" (Borrell Fontelles, 2021, str. 11). Posebno je zabrinjavajuće što je do strateškog iznenađenja došlo unatoč tome što većina država u strateškim dokumentima sigurnosti uočava pandemije, epidemije ili zarazne bolesti kao prijetnje nacionalnoj sigurnosti. Analiza strategija nacionalne sigurnosti država koje su predmet ove analize to potvrđuje.

Republika Hrvatska se u kontekstu zaraznih bolesti u Strategiji nacionalne sigurnosti referira na potrebu razvoja mjera prevencije i izgradnje sposobnosti u području javne zdravstvene zaštite usmjerene na sprječavanje zaraznih bolesti (Hrvatski sabor, 2017, str. 17). Strategija nacionalne sigurnosti SAD-a borbu protiv bioloških prijetnji i pandemija, uz ocjenu kako imaju "potencijal za uzrokovanje katastrofalnih gubitaka ljudskih života", navodi među prvim prijetnjama kojima se strategija bavi. Pritom se kao prioritetna aktivnost navodi potreba unaprjeđenja brzog odgovora i jedinstvenog sustava koordinacije kako bi se brzo provela karakterizacija epidemije, primijenile mjere javnog zdravstva i ograničilo širenje bolesti, uključujući i potrebne mjere za spašavanje života (The President of the United States, 2017, str. 9). Ruska Strategija nacionalne sigurnosti također upozorava da su epidemije proširene te da su mnoge od njih uzrokovane novim i nepoznatim virusima. Epidemije i pandemije pritom se tretiraju prijetnjama nacionalnoj sigurnosti (President of the Russian Federation, 2015, str. 4 i 13). Talijanski strateški sigurnosni dokumenti rizike pandemija razmatraju u kontekstu prijetnji nacionalnom integritetu, suverenitetu i vitalnim interesima (The Ministry of Defence, 2015, str. 16). Mađarska Strategija nacionalne sigurnosti također je imala odredbe kojima se pozivalo na uklanjanje rizika od epidemija i osiguravanje javnozdravstvene prevencije epidemija (Ministry of Foreign Affairs of Hungary, 2012, str. 14-15). Slovenska Strategija nacionalne sigurnosti procjenjuje kako zbog epidemija i pandemija može doći do ugrožavanja nesmetanog djelovanja ključnih društvenih i državnih funkcija te međunarodne stabilnosti (Državni zbor, 2019, str. 6). Srbijanska Strategija nacionalne sigurnosti uočava važne aspekte koji su se potvrdili kroz recentnu pandemiju COVID-19. Stra-

đenja podrazumijeva neuspjeh ranog upozoravanja. U tom je smislu snaga iznenađenja obrnuto proporcionalna vremenu i jasnoći ranog upozorenja, ako ono postoji. Treće, iznenadni napad razotkriva žrtvin neuspjeh da adekvatno odgovori na opasnost (Kam, 2004, str. 8-9). 
tegijom se upozorava kako epidemije i pandemije zaraznih bolesti "mogu ugroziti stanovništvo Republike Srbije", ali i da "nose rizik za nastanak težih ekonomskih i društvenih posljedica". Uočava se i aspekt iznenađenja kroz konstataciju kako epidemije zaraznih bolesti imaju karakteristiku "neuobičajenosti po broju, vremenu, mjestu i zahvaćenoj populaciji" te mogu uzrokovati i povećanje broja oboljelih $\mathrm{s}$ komplikacijama, pojavu teških kliničkih oblika zaraznih bolesti i smrti (Narodna skupština Republike Srbije, 2019, str. 9-10). Kina, kao ishodišna zemlja pandemije COVID-19, također je uočavala problematiku širenja zaraznih bolesti te je između ostalog u svom petogodišnjem planu za razdoblje 2016.-2020. navela kako će jačati međunarodnu razmjenu i suradnju na zdravstvenoj zaštiti i prevenciji epidemija te ojačati sposobnost zajedničkog rješavanja hitnih slučajeva javnog zdravstva s drugim državama (Central Committee of the Communist Party of China, 2016, str. 148). Takvo se opredjeljenje nije potvrdilo u praksi po izbijanju zaraze uzrokovane virusom COVID-19. Isto tako, kao što se vidi u navedenim razmjerima krize, nije potaklo ustrojavanje učinkovitih sustava prevencije i kriznog postupanja.

Analiza strategija pokazuje da su u njima uočeni svi važni elementi i aspekti koji karakteriziraju pandemiju COVID-19. Uočeno je kako pandemije imaju potencijal za: ugrožavanje suvereniteta i vitalnih interesa, uzrokovanje katastrofalnih gubitaka ljudskih života, ugrožavanje nesmetanog djelovanja ključnih društvenih i državnih funkcija i međunarodne stabilnosti te iznenađenje na osnovi karakteristike neuobičajenosti po broju, vremenu, mjestu i zahvaćenoj populaciji.

Uz to je uočena potreba: brzog odgovora i jedinstvenog sustava koordinacije, brze karakterizacije epidemije kako bi se primijenile mjere javnog zdravstva i ograničilo širenje bolesti, izgradnje mjera prevencije i sposobnosti u području javne zdravstvene zaštite, jačanja međunarodne razmjene i suradnje na zdravstvenoj zaštiti i prevenciji epidemija.

\section{Mjere odgovora na krizu}

Pojava i širenje virusa COVID-19 i formalno su dobili globalni karakter 30. 1. 2020. kada je Svjetska zdravstvena organizacija (WHO) proglasila izvanredno stanje za javno zdravstvo međunarodne razine. Izbijanje pandemije pratio je, $\mathrm{u}$ analiziranim državama, već sredinom veljače 2020. intenzivan rast broja oboljelih (Slika 1.), a i, što je posebno zabrinjavalo, velik rast broja umrlih osoba (Slika 2.).

Države su se suočavale sa značajnim dilemama. S jedne strane postojala su mišljenja kako su za "kontrolu trenutne epidemije potrebne... opsežne mjere za smanjenje prijenosa COVID-19 od osobe do osobe" (Vasilj i Ljevak, 2020, str. 12), a s druge upozorenja kako su "pozitivni aspekti mjera socijalnog distanciranja nedvojbeni, a sporije širenje infekcije smanjuje rizik od preopterećenja zdravstvenih usta- 
Slika 1. Dnevni broj oboljelih na milijun stanovnika (Our World Data, 2020)

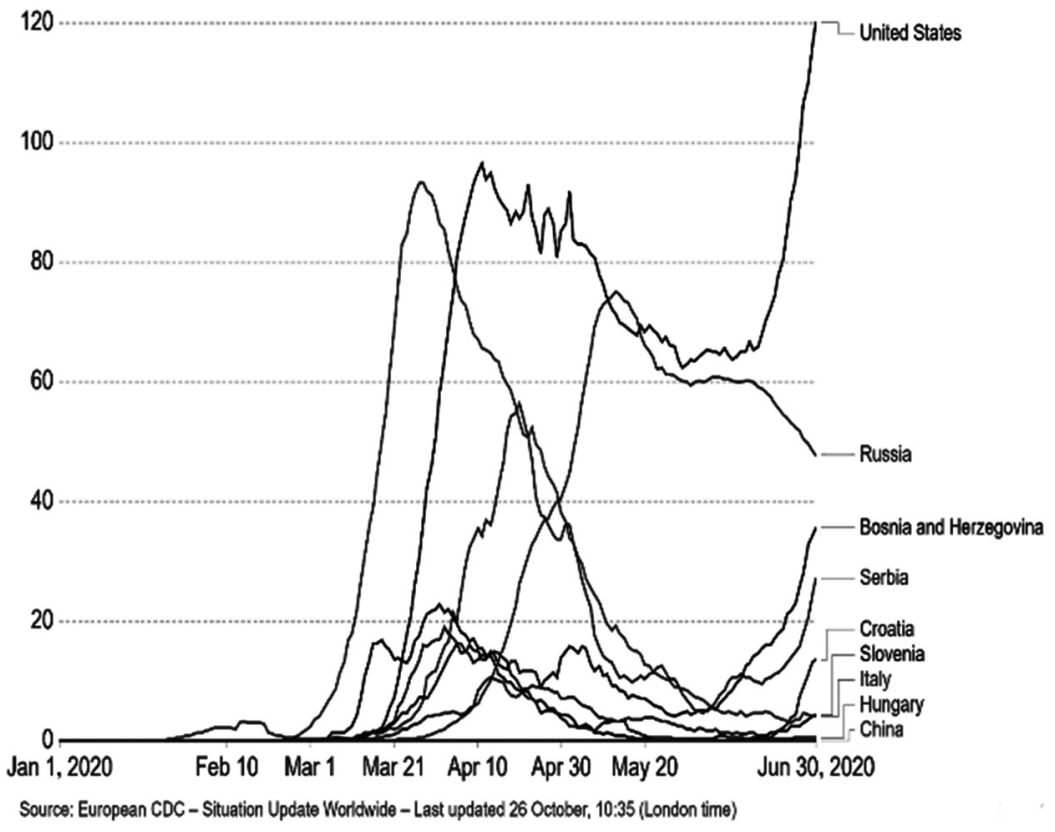

Slika 2. Dnevni broj umrlih na milijun stanovnika (Our World Data, 2020)

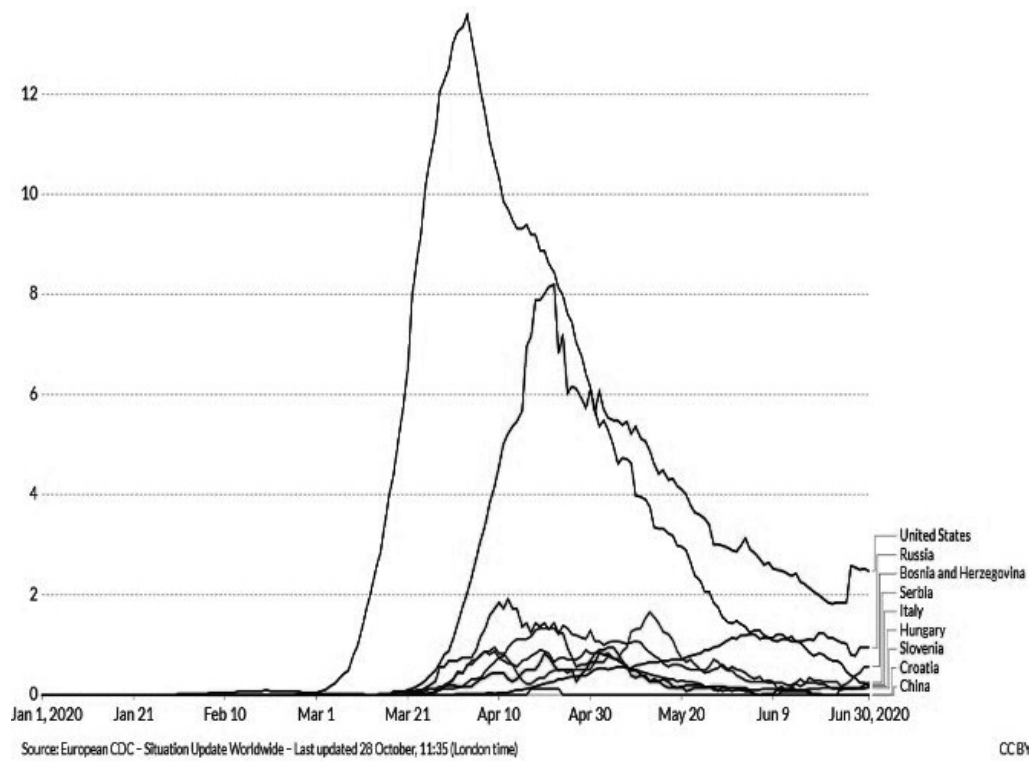


nova. Međutim te mjere također mogu produljiti pandemiju i ograničenja usvojena radi njenog ublažavanja" (Douglas i sur., 2020, str. 1).

Promatrane države reagirale su, barem u formalnom smislu, vrlo brzo proglasivši izvanredno stanje ili stanje epidemije (Tablica 1.), što je pretpostavljalo i poduzimanje niza specifičnih i izvanrednih mjera. Primarni cilj bio je zaustaviti širenje epidemije i prevenirati veliku smrtnost.

Tablica 1. Reakcija promatranih država na pojavu pandemije

\begin{tabular}{|c|c|c|c|c|c|c|c|c|c|}
\hline & $\mathrm{BiH}$ & Hrvatska & Italija & Kina & Mađarska & Rusija & SAD & Slovenija & Srbija \\
\hline $\begin{array}{l}\text { Prvi } \\
\text { oboljeli }\end{array}$ & $\begin{array}{c}5.3 . \\
2020 .\end{array}$ & $\begin{array}{l}25.2 . \\
2020 .\end{array}$ & $\begin{array}{l}31.1 . \\
2020 .\end{array}$ & \begin{tabular}{c|}
8.1. \\
$2020 .{ }^{6}$
\end{tabular} & $\begin{array}{l}4.3 . \\
2020 .\end{array}$ & $\begin{array}{l}31.1 . \\
2020 .\end{array}$ & $\begin{array}{l}21.1 . \\
2020 .\end{array}$ & $\begin{array}{l}4.3 . \\
2020 .\end{array}$ & $\begin{array}{c}6.3 . \\
2020 .\end{array}$ \\
\hline $\begin{array}{l}\text { Proglašeno } \\
\text { izvanredno } \\
\text { stanje }\end{array}$ & $\begin{array}{l}17.3 . \\
2020 .^{7}\end{array}$ & $X$ & $\begin{array}{l}31.1 . \\
2020 .\end{array}$ & $\mathrm{x}$ & $\begin{array}{l}11.3 . \\
2020 .\end{array}$ & $X$ & $\mathrm{X}$ & $X$ & $\begin{array}{l}15.3 . \\
2020 .\end{array}$ \\
\hline $\begin{array}{l}\text { Proglašena } \\
\text { epidemija }\end{array}$ & $\mathrm{X}$ & $\begin{array}{l}11.3 . \\
2020 .{ }^{8}\end{array}$ & $\mathrm{x}$ & $\begin{array}{c}\text { Kraj } \\
\text { siječnja } \\
2020 .{ }^{9}\end{array}$ & & $x^{10}$ & $\begin{array}{l}31.1 . \\
2020 .\end{array}$ & $\begin{array}{c}12.3 . \\
2020 .{ }^{11}\end{array}$ & $\mathrm{X}$ \\
\hline
\end{tabular}

${ }^{6}$ Bolest uzrokovana respiratornim problemima uočena je krajem 2019.

${ }^{7}$ Vijeće ministara BiH proglasilo je, potaknuto epidemijom, izvanredno stanje 17. 3. 2020. i aktiviralo rad Koordinacijskog tijela za zaštitu i spašavanje ljudi i materijalnih dobara od prirodnih i drugih nesreća u BiH (Vijeće ministara Bosne i Hercegovine, 2020), čime je pokrenuto djelovanje mehanizma kriznog upravljanja. Karakteristika $\mathrm{BiH}$ je da su većinu mjera zasebno uvodila dva postojeća entiteta i jedan distrikt. Naravno, takav sustav negativno je utjecao na koherentnost provedbe. Dovoljno je naglasiti da je, unatoč tome što je na razini države izvanredno stanje proglašeno 17. 3. 2020., Republika Srpska izvanredno stanje proglasila 28. 3. s početkom važenja od 3. 4. 2020.

${ }^{8}$ U Hrvatskoj je proglašena epidemija (Ministar zdravstva donio je Odluku o proglašenju epidemije bolesti COVID-19, uzrokovane virusom SARS-CoV-2), ali ne i izvanredno stanje.

9 Iako epidemija formalno nije proglašena, krajem siječnja osnovana je specijalna grupa za kontrolu epidemije, a krajem siječnja 2020. na razini provincija proglašeno je izvanredno stanje za javno zdravlje.

${ }^{10}$ Iako epidemija formalno nije proglašena, rusko ministarstvo zdravstva donijelo je upute za postupanje u epidemiji COVID-19, čime je posredno stanje definirano kao epidemija.

11 Radilo se o za Sloveniju složenom razdoblju promjene vladajuće koalicije, tranzicije vlasti i formiranja nove vlade. Epidemiju COVID-19 proglasila je 12. 3. 2020. vlada Marjana Šareca, koju je dan kasnije naslijedila vlada pod vodstvom Janeza Janše. Nova vlada već je na prvoj sjednici 13. 3. 2020. osnovala Krizni stožer Republike Slovenije za svladavanje i kontrolu epidemije COVID-19 (Vlada Republike Slovenije, 2020a). 
Mjere koje su države poduzimale možemo promatrati na nekoliko razina: zdravstveno determinirane mjere, gospodarski determinirane mjere i politički determinirane mjere. Kako se u brojnim aspektima radilo o izvanrednim mjerama usmjerenim na sprječavanje pogibelji i očuvanje sigurnosti pojedinaca, ekonomske sigurnosti, a time i nacionalne sigurnosti država, možemo govoriti o procesima sekuritizacije kao aspektu odgovora na krizu. U tom je smislu, uz navedene mjere i aktivnosti nositelja vlasti, sekuritizatora, koji su ih definirali i implementirali, važno u obzir uzeti i odgovor javnosti.

\section{Zdravstvene mjere}

Analizom mjera koje su se poduzimale temeljem zdravstvenih zahtjeva sprječavanja širenja bolesti uz prilagodbe zdravstvenog i bolničkog sustava kako bi što učinkovitije odgovorio na izazove pandemije, utvrđujemo da su primijenjene sljedeće:

- Ograničavanje kretanja i okupljanja ljudi. Ta je mjera obuhvaćala kretanje ljudi unutar država - samoizolaciju, zabranu javnih okupljanja, zatvaranje obrazovnih institucija i prelazak na online nastavu, zabranu rada ugostiteljskih i drugih uslužnih objekata kod kojih se ostvaruje bliski kontakt s klijentom, ograničavanje kretanja na određene dijelove države, pa čak u nekim državama i policijski sat.

- Pojačan je nadzor putnika u javnom transportu. Restrikcije su uvođene u vezi s ulaskom vlastitih i stranih državljana na prostor države - obvezne, najčešće četrnaestodnevne izolacije, zabrana ulaska u državu. ${ }^{12}$

- Najavljivane su, a u nekim državama i uvedene ${ }^{13}$ mjere praćenja kretanja oboljelih i onih u samoizolaciji putem mobilnih aplikacija. Rasprava se nije otvarala samo na nacionalnoj razini, uključujući i Hrvatsku, već i na razini EU-a kroz aktivnosti Europske komisije ${ }^{14}$ i Europskog parlamenta ${ }^{15}$. Pre-

${ }^{12} \mathrm{BiH}$ je 15. 3. 2020. uvela 14-dnevnu izolaciju za sve koji su ulazili u zemlju i zabranu ulaska u zemlju državljana država manje zahvaćenih epidemijom, a 24. 3. 2020. bio je zabranjen ulazak svih stranaca u zemlju. Hrvatska je već 2. 2. 2020. uvela posebne mjere za osobe koje su dolazile iz Kine.

13 Večernji list, Istražili smo: Kako države diljem svijeta nadziru mobitele u vrijeme pandemije, 31. 3. 2020.

${ }^{14}$ Vidi: Europska komisija, Komunikacija Komisije, Smjernice za zaštitu podataka u aplikacijama kojima se podupire suzbijanje pandemije bolesti COVID-19 (2020/C 124 I/01); The European Commission (2020), Commission Recommendation (EU) 2020/518 of 8 April 2020 on a common Union toolbox for the use of technology and data to combat and exit from the COVID-19 crisis, in particular concerning mobile applications and the use of anonymised mobility data. Dostupno na https://eur-lex.europa.eu/eli/reco/2020/518/oj (15. 1. 2021.).

15 Vidi: European Parliament (2020), EU coordinated action to combat the COVID-19 pandemic and its consequences. Parliament resolution of 17 April 2020 on EU coordinated action to combat the COVID-19 pandemic and its consequences (2020/2616(RSP)). 
poručene su mjere za razvoj zajedničkog pristupa EU-a primjeni mobilnih aplikacija i podataka za odgovor na pandemiju koronavirusa. Najava navedenih mjera otvorila je brojne rasprave u vezi s mogućnošću zloporaba i kršenja ljudskih prava.

Tablica 2. Poduzete mjere u promatranim državama u vezi s pojavom pandemije

\begin{tabular}{|l|c|c|c|c|c|c|c|c|c|}
\hline & $\mathrm{BiH}$ & Hrvatska & Italija & Kina & Mađarska & Rusija & SAD & Slovenija & Srbija \\
\hline $\begin{array}{l}\text { Zatvaranje } \\
\text { obrazovnih } \\
\text { institucija }\end{array}$ & $\mathrm{X}$ & $\mathrm{X}$ & $\mathrm{X}$ & $\mathrm{X}$ & $\mathrm{X}$ & $\mathrm{X}$ & & $\mathrm{X}$ & $\mathrm{X}$ \\
\hline $\begin{array}{l}\text { Ograničavanje } \\
\text { kretanja po } \\
\text { prostoru države }\end{array}$ & $\mathrm{X}$ & $\mathrm{X}$ & $\mathrm{X}$ & $\mathrm{X}$ & & $\mathrm{X}$ & & $\mathrm{X}$ & $\mathrm{X}$ \\
\hline $\begin{array}{l}\text { Ograničenje } \\
\text { ulaska u državu } \\
\text { i karantena }\end{array}$ & $\mathrm{X}$ & $\mathrm{X}$ & $\mathrm{X}$ & & $\mathrm{X}$ & $\mathrm{X}$ & $\mathrm{X}$ & $\mathrm{X}$ & $\mathrm{X}$ \\
\hline $\begin{array}{l}\text { Zabrana javnih } \\
\text { okupljanja }\end{array}$ & $\mathrm{X}$ & $\mathrm{X}$ & $\mathrm{X}$ & $\mathrm{X}$ & $\mathrm{X}$ & & & $\mathrm{X}$ & $\mathrm{X}$ \\
\hline Policijski sat & $\mathrm{X}$ & & & & & & & & $\mathrm{X}$ \\
\hline
\end{tabular}

Uvedene mjere su u većini država rezultirale značajnim smanjenjem broja oboljelih te već tijekom svibnja dolazi do smanjivanja restrikcija. Slovenija je vrlo brzo, već 15. 5. 2020., kao prva u Europi, objavila kraj epidemije (Vlada Republike Slovenije, 2020b). Pratile su je i druge države, uključujući Hrvatsku.

\section{Gospodarske mjere}

Kao što je navedeno, pandemija i prateće mjere odgovora generirale su izuzetno negativne posljedice za gospodarske aktivnosti i gospodarski sustav u cjelini. ${ }^{16}$ Dolazilo je do zatvaranja cijelih gospodarskih grana, što je potenciralo socijalni problem kako s obzirom na zaposlenike tako i s obzirom na poslodavce. To je države poticalo na izvanredne mjere pomoći gospodarstvu kako bi se očuvali poslovni subjekti i

${ }^{16}$ Vezano uz utjecaj krize na gospodarstvo Republike Hrvatske, vidi šire u: Državni zavod za statistiku Republike Hrvatske (2021), Učinci pandemije bolesti COVID-19 na društvenoekonomske pokazatelje. Dostupno na https://www.dzs.hr/Hrv/Covid-19/bdp_2_q.html (15. 1. 2021.) i Rogić Dumančić, L. (2020), Utjecaj COVID-19 krize na hrvatsko gospodarstvo. Dostupno na http://www.hde.hr/ekonomskapolitikahrvatske/publikacija/eph2001/004_Rogic_Bogdan_Raguz.pdf(15.1.2021.). 
zaposlenost te ublažile posljedice epidemije. ${ }^{17}$ Radilo se o potpori ekonomiji i domaćinstvima koja se primarno, prema podacima Međunarodnog monetarnog fonda (International Monetary Fund, 2021), odnosila na:

Fiskalne mjere

- socijalne potpore i osiguravanje minimalnih plaća zaposlenika, potpore nezaposlenima (BiH, Hrvatska, Italija, Kina, Mađarska, Rusija, SAD, Slovenija, Srbija),

- relokaciju proračunskih sredstava u zdravstveni sektor (BiH, Hrvatska, Italija, Kina, Mađarska, Rusija, SAD, Slovenija, Srbija),

- mjere za ublažavanje fiskalnog tereta za poduzeća i socijalnih doprinosa poslodavaca (Hrvatska, Italija, Kina, Mađarska, Rusija, SAD, Slovenija, Srbija).

Monetarne mjere:

- moratorije ili restrukturiranje otplate određenih skupina kredita i odgoda plaćanja režija (BiH, Hrvatska, Italija, Kina, Mađarska, Rusija, SAD, Slovenija, Srbija),

- mjere za održavanje likvidnosti (Hrvatska, Italija, Kina, Mađarska, Rusija, SAD, Slovenija, Srbija),

- subvencioniranje kamata (Mađarska, Rusija), smanjivanje kamatnih stopa (Kina, Rusija, SAD, Srbija) i garancije na kredite (SAD, Slovenija, Srbija), uvođenje instrumenata za poticanje kreditiranja (Kina, SAD),

- promjena metodologije izračuna rizika u cilju stimulacije financiranja $(\mathrm{Ru}-$ sija),

- intervencije na deviznom tržištu kako bi se održala stabilnost tečaja tijekom razdoblja krize (Hrvatska, Kina, Srbija), otkup tržišnih viškova strateških dobara (Hrvatska) i druge mjere potpore gospodarstvu.

Naravno, mjere potpore gospodarstvu pratili su i brojni prijepori oko pitanja dopuštenosti državne intervencije i zaštitnih mjera u zemljama članicama EU-a.

17 U Hrvatskoj je Vlada uvela zabranu podizanja cijena za velik broj prehrambenih, sanitacijskih i zaštitnih proizvoda, uvedene su odgode plaćanja poreza i otplata kredita te direktna financijska pomoć gospodarstvu za održanje zaposlenosti te subvencioniranje plaća. Vidi šire u: Deloitte, Vlada iznijela prijedlog mjera za pomoć gospodarstvu uslijed epidemije koronavirusa, ožujak 2020. Dostupno na https:/www2.deloitte.com/hr/hr/pages/tax/articles/vlada-prijedlog-mjeragospodarstvo-koronavirus.html (15. 1. 2021.); Drugi paket mjera Vlade RH za pomoć gospodarstvu uslijed epidemije koronavirusa, travanj 2020. Dostupno na https://www2.deloitte.com/ $\mathrm{hr} / \mathrm{hr} /$ pages/tax/articles/covid-19-vlada-prijedlog-mjera-gospodarstvo-koronavirus.html (15. 1. 2021.). 


\section{Političke mjere}

Pandemija je svojim zdravstvenim, socijalnim i gospodarskim aspektima neminovno utjecala i na političke procese otvarajući pojačanu raspravu o javnim politikama, politikama odgovora na krizu i samim nositeljima vlasti. Uz već navedene prijepore o mogućnosti zloporaba vezanih uz mobilne aplikacije kojima bi se pratilo kretanje oboljelih, pozornost se usmjeravala na održavanje parlamentarnih izbora.

- Za neke države 2020. bila je i izborna godina. ${ }^{18}$ Mjere odgovora na krizu značajno su utjecale na mobilnost predstavnika političkih stranaka i birača, što je utjecalo na sadržaj, dinamiku i učinkovitost izborne promidžbe te konačno i na izlazak na biračka mjesta. Predstavnici vladajućih stranaka u takvim su uvjetima temeljem dnevne političke aktivnosti bili u prednosti. Uz to su se i termini održavanja izbora i potencijalne manipulacije terminom od vladajućih političkih struktura nametali kao središnje političko pitanje. ${ }^{19}$ Uz to se problematiziralo kako se mjere borbe protiv epidemije ublažavaju neutemeljeno, kako popuštanje mjera nije zdravstveno opravdano te kako se mjere ublažavaju zbog izbora. Iako je to razumljiv dio političke borbe, kako sa strane vlasti tako i sa strane oporbe, sve je to dovodilo u pitanje ne samo demokratski proces i zahtjev jednakih uvjeta za sve sudionike izbornog procesa nego i povjerenje javnosti u borbu s epidemijom.

- Posebnu pozornost zaokupljali su pokušaji zloporabe režima izvanrednih stanja za jačanje represivnih i drugih ovlasti vlastodržaca. Mađarska nacionalna skupština usvojila je 30. 3. 2020. novi Zakon o izvanrednom stanju i ovlastila predsjednika Vlade da tijekom izvanrednog stanja upravlja dekretima (Library of Congress, 2020). ${ }^{20}$ Istim Zakonom penalizira se i širenje dezinformacija koje ometaju borbu protiv pandemije, što je oporba protumačila kao mogućnost cenzure i ograničavanja političkih prava.

\section{Sigurnosne prijetnje koje prate pandemiju}

Kriza potaknuta pandemijom COVID-19 pokazuje se višedimenzionalnom te nadilazi isključivo zdravstvene, humanitarne, socijalne i gospodarske aspekte. Turkcan

${ }^{18}$ Pregled izbora i referenduma u Europi može se naći na: Council of Europe (2020), Impact of COVID-19 on elections and referenda in Europe. Dostupno na https://www.coe.int/en/web/electoral-assistance/elecdata-covid-impact (15. 1. 2021.).

${ }^{19}$ U Srbiji su parlamentarni izbori održani 21. 6. 2020. Opravdanost prigovora o manipulaciji izborima potvrdilo je ponovno jačanje restriktivnih mjera neposredno nakon provedenih izbora. Predsjednik Srbije Vučić je već 7. 7. 2020. u svom obraćanju naveo kako je taj dan "najteži dan u Srbiji jer je preminulo 13 osoba, a 120 oboljelih je na respiratoru" i najavio "ponovnu mogućnost uvođenja policijskog sata" (Predsjednik Republike Srbije, 2020).

${ }^{20}$ Nacionalna skupština ukinula je izvanredno stanje 16. 6. 2020. 
upozorava kako "pandemija COVID-19 predstavlja egzistencijalnu prijetnju ljudskoj sigurnosti" te kako "pandemije ne samo uzrokuju povećanu razinu smrtnosti već i negativno utječu na ekonomsku, socijalnu i političku strukturu zemlje" (Turkcan, 2020, str. 1).

Prijetnje su generirane i neizvjesnošću te nedostatkom podataka o samoj prirodi bolesti koja je generirala pandemiju. Naime, u vezi s Kinom kao ishodištem pandemije temeljno obilježje bila je sumnja da je Kina selektivno i s upitnom točnošću informirala kako o širenju bolesti ${ }^{21}$ tako i o mjerama koje su poduzimane. S druge strane Mike Ryan, izvršni direktor programa WHO za izvanredna zdravstvena stanja, čestitao je zdravstvenim djelatnicima i stanovništvu u Kini na obuzdavanju epidemije (Burki, 2020, str. 1). Kina je vrlo brzo blokirala prostore zahvaćene epidemijom, raspolagala je uz to i s velikim količinama zaštitne opreme, a stanovništvo se pridržavalo propisanih mjera (šire u ibid., str. 1-2). Međutim međunarodni ekspertni tim WHO-a dobio je tek početkom 2021. - dakle više od godinu dana nakon izbijanja epidemije u Kini, $i$ to ne bez zapreka ${ }^{22}$ - suglasnost kineskih vlasti da dođe $u$ Kinu i Wuhan te istraži još uvijek otvorena pitanja o porijeklu bolesti COVID-19.

Poduzete mjere i same su generirale određene sigurnosne prijetnje. Javne rasprave o socijalnim i društvenim posljedicama masovnih karantena i zaključavanja, kako navodi Božić (2021, str. 14), "uglavnom su bile koncentrirane na trajne promjene i buduće scenarije za svakodnevni život koji su uključivali pojavu viših razina društvene kontrole putem novih aplikacija za pametne telefone, poremećaje u međugeneracijskoj interakciji, produbljivanje krize demokracije (...)". Kriza tako generira širi spektar sigurnosnih prijetnji koje zbog poremećaja u djelovanju i/ili refokusiranju ključnih društvenih i državnih funkcija predstavljaju izazov vitalnim interesima, pa i suverenitetu država i međunarodnoj stabilnosti.

\section{Gospodarske prijetnje}

Kriza je odmah u početku narušila lance opskrbe, izazvala nestašicu određenih strateških dobara i pokazala ovisnost čak i najrazvijenijih i tehnološki najnaprednijih država o opskrbi medicinskom opremom iz jedne države, Kine. Nestašica je ugrožavala i djelovanje zdravstvenog sustava (World Health Organization, 2020b). Radilo se o sigurnosnoj prijetnji par excellence za nacionalnu sigurnost država. Takva situacija generirala je i druge/nove prijetnje od državnih i nedržavnih aktera - jača-

${ }^{21}$ Vidi: Congressional Research Service, COVID-19 and China: A Chronology of Events (December 2019-January 2020), CRS Report, 13. 5. 2020., str. 4-12.

${ }^{22}$ Jutarnji list, Tek što su stigli, strani eksperti naletjeli na prve prepreke. Kina, čini se, želi kontrolirati istragu, 14. 1. 2021. Dostupno na https://www.jutarnji.hr/vijesti/svijet/tek-sto-su-stiglistrani-eksperti-naletjeli-na-prve-prepreke-kina-cini-se-zeli-kontrolirati-istragu-15042859 (17. 1. 2021.). 
nje kriminalnih aktivnosti, dezinformacijskih aktivnosti i aktivnosti ekstremističkih skupina te pokušaja rekonfiguracije globalnih odnosa moći. Prema istraživanjima Joshue Kurlantzicka, pandemija je "dodatno ojačala ekonomske i socijalne nejednakosti", a "politike koje su produbljivale nejednakost često su pogoršavale situaciju" (Kurlantzick, 2021, str. 2 i 6). Kina je, u situaciji u kojoj je, potaknuto krizom, značajno pala vrijednost brojnih zapadnih tvrtki koje su se suočile s ograničenjima i problemima, iskazivala velik interes za njihovo preuzimanje. To je otvorilo rasprave o poduzimanju mjera kojima bi američka i europske vlade ograničile prodaju tvrtki u problemima, osobito u osjetljivim sektorima. ${ }^{23}$

\section{Geopolitičke prijetnje}

Pojedini državni akteri, posebno iz autokratskih sustava, svjesni da učinkovitost postupanja u uvjetima kriza značajno determinira status država i njihovog vodstva na vanjskom i unutarnjem političkom planu, takvu su situaciju koristili za ideološko nadmetanje. Pritom su, svjesni da je demokratski proces znatno zahtjevniji, posebno u nametanju ograničenja kretanju i drugim osobnim slobodama, i da uvođenje potrebnih kriznih mjera otvara društvenu raspravu, kao sredstvo koristili primarno informacijske i dezinformacijske operacije te tajne operacije preko društvenih mreža. Cilj je tih operacija s jedne strane bio popraviti međunarodni imidž njihovih nositelja (Kina se npr. trudila otkloniti odgovornost za izbijanje pandemije), a s druge ukazati na nesposobnost demokratskih država da učinkovito odgovore na krize. Pritom se npr. problematiziralo EU i SAD te njihovo postupanje u krizi i širila se konfuzija o porijeklu ${ }^{24}$ i zdravstvenim implikacijama virusa COVID-19. Pandemija se kontinuirano predstavljala kao slabost demokratskih sistema da učinkovito upravljaju krizom (European External Action Service, 2020, str. 4). Poruke iz Kine, zajedno s onima iz Irana i Rusije, sugerirale su da su odgovori demokratskih zemalja na širenje bolesti COVID-19 bili katastrofalni, a da su autokratske države dobro upravljale pandemijom (Kurlantzick, 2020). Iz EU-a su dolazili odgovori kako su, "unatoč potencijalno ozbiljnom utjecaju na javno zdravlje, službeni i državni izvori iz različitih vlada, uključujući Rusiju i - u manjoj mjeri - Kinu nastavili širiti i usmjeravati narative zavjere i dezinformacije prema javnosti kako EU-a tako i šireg

${ }^{23}$ Vidi: Foreign Policy (2020), China Is Bargain Hunting - and Western Security Is at Risk, 15. 4. 2020. Dostupno na https://foreignpolicy.com/2020/04/15/china-is-bargain-hunting-and-western-security-is-at-risk/ (16.1.2021.) i The Washington Post, How China is planning to use the coronavirus crisis to its advantage, 16. 3. 2020. Dostupno na https://www.washingtonpost.com/ opinions/2020/03/16/how-china-is-planning-use-coronavirus-crisis-its-advantage/ (16. 1. 2021).

${ }^{24}$ Ruska vojna obavještajna služba širila je dezinformacije kojima su se osnaživale kineske tvrdnje kako je virus stvoren u SAD-u, kako je koronavirus napor SAD-a da nametne svoju viziju "svjetskog poretka" te kako je COVID-19 eksperiment za manipulaciju svijetom (The Hill, 2020; Department of Homeland Security, 2020, str. 11-12). 
susjedstva" (European External Action Service, 2020, str. 2). Rastuće zaoštravanje međuodnosa ključnih subjekata na međunarodnoj sceni dodatno aktualizira zabrinutost "da odnosi u međunarodnoj zajednici teže kompeticiji, a ne suradnji" koju u kontekstu analize geopolitičkih učinaka pandemije COVID-19 iznose Zorko i Lučev (2021, str. 91). Osim što je podloga za geopolitička nadmetanja, "širenje pogrešnih informacija i dezinformacija te teorija zavjere prijetnja je demokraciji (...) te uzrok rastućeg nepovjerenja u vlade i medije" (European Commission, 2020, str. 20) kao bitne sastavnice demokratskog sustava.

\section{Političke prijetnje}

Osim borbe za dominacijom na globalnoj sceni, cilj tih aktivnosti bile su i domaće javnosti. Nositelji su tako domaće javnosti uvjeravali u sposobnosti vlastitih političkih elita. Stvaranju konfuzije pridonosile su i vladajuće političke elite samih demokratskih država. S jedne strane to je bilo početno nesnalaženje u odgovoru na krizu, koje se za razliku od prakse autokratskih država nije moglo sakriti od javnosti, a s druge je dolazilo i do političkih manevara s upitnim utemeljenjem koji se mogu tumačiti kao korištenje pandemije za postizanje partikularnih političkih probitaka koji konačno dovode, tj. mogu dovesti do značajnih sigurnosnih prijetnji na osnovi derogiranja demokratskih standarda. Tu se primarno misli na u radu već obrađene aktivnosti pojedinih političkih aktera vezane uz:

- termine održavanja izbora, prvenstveno kroz pokušaj osiguravanja za vlast politički najpovoljnijeg trenutka,

- jačanje izvršnih ovlasti uz istovremeno smanjivanje odgovornosti prema predstavničkim tijelima,

- rasprave o modalitetima praćenja oboljelih putem mobilnih aplikacija, koje su u javnosti izazivale zabrinutost zbog mogućeg ograničavanja sloboda te neustavnog i nedemokratskog zadiranja u privatnost građana.

Kako stanje potaknuto pandemijom ugrožava demokratske standarde vidljivo je iz izvješća izrađenog za Freedom House (Repucci i Slipowitz, 2020), prema kojem je od izbijanja pandemije, već u prvoj fazi, koja je i predmet ove analize, došlo do "pogoršanja demokratskih uvjeta i ljudskih prava u osamdeset država svijeta", i to u područjima zloporabe vlasti, marginalizacije pojedinih zajednica, transparentnosti i borbe protiv korupcije, medija i slobode izražavanja te izbora. Među osamdeset navedenih država nalaze se i analizirane Kina, Mađarska, Slovenija, SAD i Srbija.

\section{Kibernetički kriminal}

Značajna posljedica uvedenih mjera obuzdavanja pandemije bila je nestašica zaštitnih sredstava s jedne strane te lockdown, tj. značajno ograničavanje kretanje ljudi s druge. Takvo stanje rezultiralo je porastom korištenja interneta za kupovinu, obav- 
ljanje posla, informiranje i zabavu, i to u "obujmu koji nikad ranije nije zabilježen" (Europol, 2020a). Takva situacija otvorila je širok prostor zloporabama kibernetičkog prostora, kibernetičkim napadima, pa i napadima na kritičnu zdravstvenu infrastrukturu, te kibernetičkom kriminalu. Kriminalci su brzo iskoristili mogućnosti koje je otvorila kriza i prilagodili načine rada ili razvili nove kriminalne aktivnosti (Europol, 2020b). Intenzivirale su se već tradicionalne phishing, ransomware i malware kampanje i krađa osobnih podataka. Online objave materijala sa seksualnim zlostavljanjem djece zabilježile su nagli skok na vrhuncu krize COVID-19 (Europol, 2020b). ${ }^{25}$ Organizirani kriminal uključio se i u online prijevare prodajom krivotvorene robe, pri čemu je posebno bila zabrinjavajuća prodaja krivotvorene zaštitne opreme, testova za COVID-19 i lijekova, ili robe koja nikad nije isporučena. ${ }^{26}$ Istovremeno je s restrikcijama kretanja došlo do kratkotrajnog smanjivanja broja ilegalnih migranata na rutama prema Europi, ali i brze prilagodbe organiziranog kriminala $i$ pojačanog angažmana u organizaciji ilegalnih migracija.

\section{Koruptivne prijetnje}

U odgovoru na krizu mogle su se uočiti i zloporabe koje ulaze u korpus koruptivnih radnji i koje kao takve čine dio spektra sigurnosnih prijetnji koje su pratile pandemiju. Odmah s uvođenjem mjera dolazi i do slučajeva profiterstva, ali, što je važnije, i sumnji u zloporabe od najviših dužnosnika. U BiH su, u tzv. "Aferi respiratori” povezanoj s koruptivnim radnjama u nabavi respiratora, krajem svibnja 2020. uhićeni premijer Federacije BiH i direktor Federalne uprave civilne zaštite. ${ }^{27}$ Radilo se o dvije najodgovornije osobe za borbu s epidemijom. Sličan je slučaj zabilježen i u Sloveniji, gdje je također radilo o pogodovanju i političkim intervencijama vladajućih u sumnjivim poslovima nabave potrebnog materijala za borbu s koronavirusom, što je završilo uhićenjem ministra gospodarstva te ostavkom ministra unutarnjih poslova i ravnatelja policije. ${ }^{28}$

25 Vidi šire u: Europol, 2020c; Department of Homeland Security, 2020, str. 9.

26 Vidi šire u: Europol, 2020b.

27 Početkom siječnja 2021. sud je u cijelosti potvrdio optužnicu podignutu protiv predsjednika vlade Federacije BiH Fadila Novalića, njegove zamjenice i ministrice financija Jelke Miličević, bivšeg ravnatelja Civilne zaštite Fahrudina Solaka i vlasnika tvrtke "Srebrena malina" Fikreta Hodžića. Optužnica ih tereti za udruživanje radi počinjenja kaznenih djela te za zloporabu položaja ili ovlasti, primanje nagrade ili drugog oblika koristi radi trgovine utjecajem. Dnevnik. hr., Podignuta optužnica protiv ministrice i premijera Federacije BiH zbog sramotne afere s respiratorima, 4. siječnja 2021. Dostupno na https://dnevnik.hr/vijesti/koronavirus/bih-potvrdjenaoptuznica-protiv-premijera-i-ministrice-zbog-nabavke-respiratora---634669.html (16. 1. 2021.).

28 Vidi šire u: 24 sata, Pogodovali pojedinim tvrtkama i "debelo" preplatili respiratore, ministri prisiljeni na ostavke! Dostupno na https://www.24sata.hr/news/pogodovali-pojedinim-tvrtkama-i-debelo-preplatili-respiratore-ministri-prisiljeni-na-ostavke-703935 (1. 11. 2020.) i Delo, Notranji minister Hojs nepreklicno odstopil, Janša odstop sprejel, 30. 6. 2020. Dostupno na 
Interes javnosti u Hrvatskoj ${ }^{29}$ potakla je odluka Vlade o nabavi zaštitne opreme preko tvrtke osnovane samo nekoliko mjeseci ranije. ${ }^{30}$

\section{Ekstremistički pokreti}

Već tijekom prvog vala mogli su se uočiti začeci protesta usmjerenih protiv ograničavanja kretanja, obveze nošenja zaštitnih maski i slično. Ti su protesti, u kojima su sudjelovali protivnici cijepljenja i drugi, dobili snažniji zamah nakon ljeta s početkom drugog vala pandemije. Značajno su tome pridonosili nejasni, često dvosmisleni i nedovoljno argumentirani stavovi, izjave i politike nositelja vlasti. Jedan od izrazitijih primjera bilo je kontinuirano protivljenje američkog predsjednika Trumpa nošenju zaštitnih maski. Takvi protesti, osim što su generirali radikalizaciju, značajno su slabili funkcionalnu sposobnost institucionalnog sustava u borbi s krizom.

Paralelno s jačanjem pandemije i povećanjem broja mjera za njeno obuzdavanje tijela provedbe zakona snažno su angažirana u provedbi mjera, održavanju reda i potpori zdravstvenom sustavu.

Nasilni ekstremisti, kako su uočili u SAD-u, iskorištavali su "javne strahove povezane s COVID-19 i društvena nezadovoljstva kako bi zakonitim prosvjedima poticali nasilje, zastrašivali i promovirali nasilne ekstremističke ideologije". Uz to se procjenjivalo kako "situacija oko pandemije COVID-19 stvara okruženje koje bi moglo ubrzati mobilizaciju nekih pojedinaca prema nasilju ili radikalizaciji za terorizam" (Department of Homeland Security, 2020, str. 18).

Snažno okretanje prema internetu i kibernetičkoj sferi tijekom pandemije kroz online rad od kuće, održavanje socijalnih kontakata, nabavu raznih vrsta proizvoda, zabavu i druge aktivnosti otvorio je novi prostor ne samo već opisanom kibernetičkom kriminalu nego i razvoju ekstremističkih djelovanja. Ajzenhamer i Rokvić (2021, str. 81) upravo u tom kontekstu, kroz analizu evolucije sekuritizacije na primjeru antivakserskih pokreta, uočavaju "kako su promjene u praksi društvenog, političkog i sigurnosnog komuniciranja, inicirane naglim uzletom digitalnih dru-

https://www.delo.si/novice/slovenija/notranji-minister-hojs-nepreklicno-odstopil-jansa-odstopsprejel/ (1. 11. 2020.).

${ }^{29}$ Tportal.hr. (2020). Vlasnik firme koja je dobila milijunski posao s maskama otkrio detalje za tportal: Ovo je na granici isplativosti, mogao bih završiti u minusu. Dostupno na https://www. tportal.hr/vijesti/clanak/vlasnik-firme-koja-je-dobila-milijunski-posao-s-maskama-otkrio-detalje-za-tportal-ovo-je-na-granici-isplativosti-mogao-bih-zavrsiti-u-minusu-foto-20200320 (16. 1. 2021).

${ }^{30}$ Odluka Vlade RH o isplati predujma od 18.937.500,00 kuna Medical and pharm trading d.o.o. za nabavu zaštitnih maski za potrebe sprečavanja širenja bolesti "COVID-19" uzrokovane virusom SARS-CoV-2. Vlada Republike Hrvatske (2021), 217. (telefonska) sjednica Vlade Republike Hrvatske. Dostupno na https://vlada.gov.hr/sjednice/217-telefonska-sjednica-vladerepublike-hrvatske-29035/29035 (16. 1. 2021.). 
štvenih medija i mreža, proizvele promjenu ustaljenih pravila sekuritizirane igre" te kako je "ekspanzija virtualnih društvenih medija i mreža omogućila građanima da političkim vlastima osporavaju sigurnosni legitimitet (...) građani posredstvom interneta postaju kreatori vlastitog sigurnosnog diskursa" (ibid., str. 67). U tom smislu mijenja se pozicija građana kao sigurnosnih subjekata.

\section{Zaključak}

Iako su sigurnosne politike suvremenih država u svojim strateškim dokumentima uglavnom akceptirale i ugrožavanje zdravstvene sigurnosti, sustavi nacionalne sigurnosti ipak nisu bili formatirani za učinkovit odgovor na ugrožavanje zdravlja ljudi zaraznim bolestima koje imaju pandemijske razmjere. Pokazalo se da su sustavi nacionalne sigurnosti i nadalje formatirani primarno za obranu države od oružane agresije, zbog čega su prvenstveno oslonjeni na elemente tvrde moći, odnosno obrambeni, policijski i sigurnosno-obavještajni segment. Pokazalo se da formalizacija pandemija/epidemija kao sigurnosnih prijetnji u strategijama sigurnosti nije bila praćena i operacionalizacijom u sustavu nacionalne sigurnosti koji bi jamčio učinkovit odgovor, kao što je to slučaj kod nekih drugih prijetnji, uključujući agresiju i terorizam.

Uz fokusiranost na državu kao središnji aspekt tradicionalne sigurnosne paradigme, potrebno je fokusirati se i na državnu strukturu, pri čemu moramo imati na umu da pandemija/epidemija nije jedina prijetnja te vrste. Tu su i prijetnje socijalnih, političkih i društvenih podjela, siromaštva, niske razine funkcionalnog znanja kod djece, koje također - često neuočljivo, ali kontinuirano - nagrizaju državnu strukturu u svim njenim aspektima. Pokazalo se da izvanredne mjere liderima s autokratskim tendencijama mogu otvarati prostor za limitiranje demokratskih standarda i pokušaje jačanja političke moći, što ukazuje na važnost ostvarivanja balansa između sigurnosti i osobnih sloboda. Praksa mnogih zemalja u prvom valu pandemije COVID-19 pokazuje da to nije nimalo jednostavna zadaća te da će zahtijevati temeljita istraživanja i analize za svrhu pronalaženja novih institucionalnih rješenja. Pritom je posebno važno osigurati dobro krizno komuniciranje ne samo radi kvalitetnog i pravodobnog upoznavanja javnosti nego i radi preveniranja učinaka dezinformacijskih kampanja. Recentna pandemija COVID-19 utjecala je na to da politika zaštite od ove opasnosti bude fokusirana na pojedinca i njegovo osvješćivanje kroz javne kampanje putem programa koji podrazumijevaju pristup široj javnosti.

Sigurnosne studije će se sve više oslanjati na konstruktivističku teoriju zbog njene fleksibilnosti u izučavanju suvremenih sigurnosnih izazova i rizika te nužnosti brze implementacije dobivenih spoznaja u političku praksu. To znači da će sve više jačati veza između znanosti i prakse, što će omogućiti intenzivniji razvoj i sigurnosnih studija, koje od začetka imaju znanstvenu dimenziju i praktičnu primje- 
njivost kako u polju politike i ekonomije tako i u različitim segmentima suvremenih društava. Sigurnosne studije i nadalje će biti usmjerene na razmatranje sigurnosnih fenomena i u okviru realističke i liberalne perspektive. Time će se sigurnosna paradigma ne samo mijenjati nego će zadržavati i određena dosadašnja obilježja, što će istraživanje sigurnosti i sigurnosnih fenomena činiti složenijim. U tom će kontekstu definiranje sigurnosnih politika i razvoj sigurnosnih sustava biti sve zahtjevniji. Posebno će biti važno razvijanje sustava kriznog upravljanja u koji treba uključiti širu zajednicu u svim fazama te sposobnost prepoznavanja potencijalnih kriza i brzog reagiranja svih sastavnica sustava. Uz to je kod globalnih prijetnji poput pandemija potrebna i učinkovita međunarodna suradnja. Tko bude bolje i učinkovitije upravljao krizama, iz njih će izlaziti politički, društveno i gospodarski kompetitivniji u odnosu na druge, što će dodatno zaoštravati kompeticiju za globalno vodstvo, a to je samo po sebi jedna od najvećih sigurnosnih prijetnji današnjice.

Pandemija COVID-19 pokazala je da je došlo do sekuritizacije te opasnosti u gotovo svim državama, ali više kao reakcija na trenutne, nepovoljne okolnosti nego na temelju neke promišljene i međunarodno usklađene politike borbe protiv nje. Međutim još uvijek nema učinkovitih nacionalnih politika, a ni zadovoljavajuće međunarodne suradnje. Ipak, ukupne mjere koje se poduzimaju u borbi s pandemijom na nacionalnim razinama dovele su do značajnog reorganiziranja i djelovanja sustava kriznih postupanja i preusmjeravanja resursa, ljudskih, tehničkih i financijskih. To je posljedično preusmjeravalo uobičajeni fokus i angažman u odnosu na sigurnosne prijetnje i otvaralo njihovim nositeljima prostor za pojačano djelovanje.

Pandemija COVID-19 imat će ozbiljne posljedice za sve aspekte državnog i društvenog organiziranja i djelovanja. Zbog toga je već u ovoj fazi trajanja pandemije važno istražiti sve njene aspekte, od političkih, ekonomskih i socijalnih do sigurnosnih. U tom će kontekstu sigurnosne studije trebati, više nego do sada, posvećivati pozornost zdravstvenim aspektima sigurnosti.

\section{LITERATURA}

Ajzenhamer, V., Rokvić, V. (2021). Kada publika postane sekuritizujući akter: Promena bezbednosne paradigme u vreme pandemije COVID-19. Sociologija i prostor, Posebno izdanje, 59 (219): 55-87.

Borrell Fontelles, J. (2021). European Foreign Policy in Times of COVID-19. Publication Office of the European Union. Luxembourg.

Božić, S. (2021). Interaction Ritual Chains and Sustainability of Lockdowns, Quarantines, "Social Distancing" and Isolation during the COVID-19 Pandemic. Sociologija i prostor, Posebno izdanje, 59 (219): 13-34. 
Burki, T. (2020). China's successful control of COVID-19, The Lancet, 20 (11): 12401241 (1. studenoga). Dostupno na: https://www.thelancet.com/action/showPdf?pii $=\mathrm{S} 1473-3099 \% 2820 \% 2930800-8$ (uvid 13. 2. 2021).

Central Committee of the Communist Party of China. (2016). The 13th Five-Year Plan for Economic and Social Development of the People's Republic of China (20162020). Dostupno na: https://www.un-page.org/files/public/china_five_year_plan. pdf (uvid 20. 10. 2020).

Department of Homeland Security. (2020). Homeland Threat Assessment, listopad.

Douglas, M. i sur. (2020). Mitigating the wider health effects of Covid-19 pandemic response. BMJ, 2020;369:m1557 (objavljeno 27. travnja). DOI: 10.1136/bmj.m1557

Državni zbor. (2019). Resolucija o strategiji nacionalne varnosti Republike Slovenije, Uradni list $R S$, br. 59/19. Dostupno na: http://www.pisrs.si/Pis.web/ pregledPredpisa?id=RESO124 (uvid 20. 10. 2020).

European Commission. (2020). 2020 Strategic Foresight Report - Charting the Course Towards a More Resilient Europe. Dostupno na: https://ec.europa.eu/info/sites/default/files/strategic_foresight_report_2020_1.pdf (uvid 15. 10. 2020).

European External Action Service. (2020). EEAS Special Report Update: Short Assessment of Narratives and Disinformation Around the COVID-19/Coronavirus Pandemic (updated 2 - 22 April). EUvsDisinfo. Dostupno na: https://euvsdisinfo.eu/eeasspecial-report-update-2-22-april/ (uvid 15. 10. 2020).

Europol. (2020a). COVID-19 Sparks Upward Trend in Cybercrime. Press Release, 5. listopada. Dostupno na: https://www.europol.europa.eu/newsroom/news/covid19-sparks-upward-trend-in-cybercrime (uvid 2. 11. 2020).

Europol. (2020b). Pandemic profiteering how criminals exploit the COVID-19 crisis, March 2020. Dostupno na: file:///C:/Users/User/Downloads/pandemic profiteering-how_criminals_exploit_the_covid-19_crisis.pdf (uvid 2. 11. 2020).

Europol. (2020c). Internet Organised Crime Threat Assessment 2020. Dostupno na: file:///C:/Users/User/Downloads/internet organised crime threat assessment iocta_2020.pdf (uvid 2. 11.2020).

Federal Reserve History. (2013). The Great Recession: December 2007-June 2009. Dostupno na: https://www.federalreservehistory.org/essays/great recession of 200709 (uvid 15. 10. 2020).

Gardini, G. L. (ur.). (2020). The World Before and After Covid-19: Intellectual Reflections on Politics, Diplomacy and International Relations. European Institute of International Studies. Salamanca - Stockholm.

Hrvatski sabor. (2017). Strategija nacionalne sigurnosti Republike Hrvatske. Narodne novine, $73 / 2017$.

Institute for Economics \& Peace. (2019). Global Terrorism Index 2019 - Measuring the Impact of Terrorism. Sydney. Dostupno na: http://visionofhumanity.org/app/ uploads/2019/11/GTI-2019web.pdf (uvid 15. 10. 2020). 
International Monetary Fund. (2021). Policy Responses to COVID-19. Dostupno na: https://www.imf.org/en/Topics/imf-and-covid19/Policy-Responses-to-COVID19\#C (uvid 8. 5. 2020).

Kam, E. (2004). Surprise attack: the victim's perspective. Harvard University Press. Cambridge, MA i London, UK.

Kolodziej, E. A. (2011). Sigurnost i međunarodni odnosi. Politička kultura i Centar za međunarodne i sigurnosne studije Fakulteta političkih znanosti Sveučilišta u Zagrebu. Zagreb.

Kurlantzick, J. (2020). How China Ramped Up Disinformation Efforts During the Pandemic. Council on Foreign Relations, 10. rujna. Dostupno na: https://www.cfr.org/ in-brief/how-china-ramped-disinformation-efforts-during-pandemic (uvid 15. 10. 2020).

Kurlantzick, J. (2021). COVID-19 and Its Effect on Inequality and Democracy. A Study of Five Large Democracies. Council on Foreign Relations, Discussion Paper, March 2021. Dostupno na: https://cdn.cfr.org/sites/default/files/report_pdf/kurlantzickdp_final_1.pdf (uvid 9. 5. 2021).

Library of Congress. (2020). Hungary: National Assembly Adopts Act Giving Government Special Powers during Coronavirus Pandemic. Dostupno na: https:// www.loc.gov/law/foreign-news/article/hungary-national-assembly-adopts-act-giving-government-special-powers-during-coronavirus-pandemic/ (uvid 15. 1. 2021).

Ministry of Foreign Affairs of Hungary. (2012). Hungary's National Security Strategy.

Narodna skupština Republike Srbije. (2019). Strategija nacionalne bezbednosti Republike Srbije. Dostupno na: https://www.pravno-informacioni-sistem.rs/SlGlasnikPortal/eli/rep/sgrs/skupstina/strategija/2019/94/2 (uvid 31. 10. 2020).

Our World Data. (2020). Coronavirus Pandemic (COVID-19) Statistics and Research. Dostupno na: https://ourworldindata.org/coronavirus (uvid 10. 10. 2020).

PewResearch Center. (2020). In many countries, people are more negative about the economy amid COVID-19 than during Great Recession. Dostupno na: https://www. pewresearch.org/fact-tank/2020/09/14/in-many-countries-people-are-more-negative-about-the-economy-amid-covid-19-than-during-great-recession/ (uvid 15. 10. 2020).

Predsjednik Republike Srbije. (2020). Obraćanje predsednika Republike Srbije 07. 07. 2020. Dostupno na: https://www.predsednik.rs/lat/pres-centar/vesti/obracanjepredsednika-republike-srbije-07072020 (uvid 15. 10. 2020).

President of the Russian Federation. (2015). Edict of the Russian Federation President On the Russian Federation's National Security Strategy, Russian Federation Presidential Edict 683, 31. prosinca. Dostupno na: https://www.russiamatters.org/sites/ default/files/media/files/2015\%20National\%20Security\%20Strategy\%20ENG_0. pdf (uvid 31. 10. 2020). 
Repucci, S., Slipowitz, A. (2020). Democracy under Lockdown - The Impact of COVID-19 on the Global Struggle for Freedom. Freedom House.

Tatalović, S., Malnar, D. (2015). Sigurnosni aspekti izbjegličke krize. Političke analize, br. 23: 23-30.

The Hill. (2020). Declasified Intel says Russia spreading coronavirus disinformation: reports. 28. 7. 2020. Dostupno na: https://thehill.com/policy/cybersecurity/509467declassified-intel-says-russia-is-spreading-coronavirus-disinformation (uvid 15. 10. 2020).

The Ministry of Defence, Republica Italiana. (2015). White Paper for international security and defence. Dostupno na: https://www.difesa.it/Primo_Piano/Documents/2015/07_Luglio/White\%20book.pdf (uvid 20. 10. 2020).

The President of the United States. (2017). National Security Strategy of the United States of America.

Turkcan, M. L. (2020). Pandemics blind spots in national security paradigms, AA 23. 5. 2020., Istanbul. Dostupno na: https://www.aa.com.tr/en/analysis/analysis-pandemics-blind-spots-in-national-security-paradigms/1851654 (uvid 16. 1. 2021).

Vasilj, I., Ljevak, I. (2020). Epidemiološke karakteristike COVID-a 19. Zdravstveni glasnik, 6 (1): 9-18.

Vijeće ministara Bosne i Hercegovine. (2020). Priopćenje i audio zapis konferencije za medije. Dostupno na: http://www.vijeceministara.gov.ba/saopstenja/sjednice/saopstenja_sa_sjednica/default.aspx?id=32584\&langTag=hr-HR (uvid 30. 11. 2020).

Vlada Republike Slovenije. (2020a). Novice. Dostupno na: https://www.gov.si/novice ?date $=3 \% 2 F 2020 \&$ nrOfItems $=20 \&$ org $\% 5 \mathrm{~B} 0 \% 5 \mathrm{D}=936 \&$ start $=40$ (uvid 30. 11 . 2020).

Vlada Republike Slovenije. (2020b). Preklic epidemije, nekateri učenci in dijaki nazaj v šole z 18. majem. Dostupno na: https://www.gov.si/novice/2020-05-15-preklicepidemije-nekateri-ucenci-in-dijaki-nazaj-v-sole-z-18-majem/ (uvid 30. 11. 2020).

Wolfers, A. (1962). Discord and Collaboration: Essays on International Politics. The Johns Hopkins Press. Baltimore.

World Bank. (2020). COVID-19 to Plunge Global Economy into Worst Recession since World War II, Global Economic Prospects, Press Release, 8. lipnja. Dostupno na: https://www.worldbank.org/en/news/press-release/2020/06/08/covid-19-to-plungeglobal-economy-into-worst-recession-since-world-war-ii (uvid 15. 10. 2020).

World Health Organization. (2020a). Archived: WHO Timeline - COVID-19. Ženeva. Dostupno na: https://www.who.int/news/item/27-04-2020-who-timeline---covid-19 (uvid 30. 11. 2020).

World Health Organization. (2020b). Shortage of personal protective equipment endangering health workers worldwide. Ženeva. Dostupno na: https://www.who.int/ news/item/03-03-2020-shortage-of-personal-protective-equipment-endangeringhealth-workers-worldwide (uvid 1. 11. 2020). 
Worldometer. (2021). Countries where COVID-19 has spread. Dostupno na: https:// www.worldometers.info/coronavirus/countries-where-coronavirus-has-spread/ (uvid 9. 5. 2021).

Zorko, M., Lučev, J. (2021). Geographical Patterns and Geo-Economic Reasoning of the Pandemic Consequences: Old Geopolitical "Games" in the Post-COVID Global Order. Sociologija i prostor, Posebno izdanje, 59 (219): 89-118.

\author{
Siniša Tatalović, Dario Malnar \\ THE COVID-19 PANDEMIC AND A NEW UNDERSTANDING \\ OF SECURITY
}

\begin{abstract}
Summary
The outbreak of the COVID-19 pandemic in early 2020 led to an unprecedented crisis of global proportions that led to the blockade of vital components of social action on a scale that threatened international and national security. The pandemic has demonstrated the potential to evolve and generate a wider range of threats and has opened up essential questions of understanding the security and security organization of states. It is a threat to which, although recognized in most strategic security documents, the response of national and international security systems has not been successfully defined within the still dominant understanding of security based on traditional security studies. It has been shown that security systems are still determined by a traditional concept that does not fully identify the causes of threats and crises and their correlations, which increases uncertainty and negatively affects the normative and institutional capacity needed to respond effectively to crises. The paper is based on the hypothesis that the COVID-19 pandemic has prompted a security paradigm shift that challenges the scientific community and policy-makers to define new approaches and new methods of researching security phenomena and strategic modelling of security systems and crisis management nationally and globally. The paper will therefore analyse the impact of the crisis triggered by the COVID-19 pandemic on understanding security through an analysis of the threats it has generated and defining the correlation between theoretical knowledge and practical crisis management experiences.
\end{abstract}

Keywords: COVID-19 Pandemic, Security, Security Policies, Security Studies, Crisis Management

Siniša Tatalović je redoviti profesor u trajnom zvanju na Fakultetu političkih znanosti Sveučilišta u Zagrebu.

Dario Malnar je docent političkih znanosti i znanstveni suradnik u polju politologije na Hrvatskom vojnom učilištu "Dr. Franjo Tuđman”. 
Kontakti:

Siniša Tatalović, Fakultet političkih znanosti, Lepušićeva 6, 10000 Zagreb. E-mail: statal@fpzg.hr

Dario Malnar, Hrvatsko vojno učilište “Dr. Franjo Tuđman”, Ilica 256b, 10000 Zagreb. E-mail: malnar.zg@gmail.com 